\title{
National and Personal Stories: Anzac and Forming a Sense of the Past for 'Ordinary Australians'
}

\author{
Lucinda Fretwell \\ The Australian National University
}

Abstract: At the conclusion of its World War I centenary commemorations, Australia's history has become increasingly politicised and militarised as governments and their agencies have mobilised national stories such as Anzac to define an Australian identity. Concerned by this development, some Australian historians have been searching for ways to counter this trend. This article explores how 'ordinary Australians' form their understandings of the past. Bringing together scholarship on how people engage with history, the history wars, Anzac and commemoration, it argues that 'ordinary' people form diverse ideas and impressions in response to their engagements with history in both the public and private spheres. It is through the intertwining of these public and private engagements, and national and personal stories, that they develop a historical sensibility. Consequently, 'ordinary' people are not so easily swayed by politicians and government organisations. Thus, historians have opportunities to engage with 'ordinary Australians' and encourage more complex understandings of both Australian history and identity.

At around 12 pm on 11 November 2018 the guns fell silent on Australia's Anzac centenary commemorations. Lasting for about five years and costing almost $\$ 600$ million, these commemorations aimed to impress on all Australians the significance and enduring legacy of our military history, and particularly our involvement in World War I (WWI). ${ }^{1}$ Speaking a few

1 See, for example, 'The Anzac Centenary National Program', Australian Government, Department of Veterans' Affairs, accessed 15 June 2019, www.anzaccentenary.gov.au/anzac-centenary-nationalprogram; 'The National Commission on the Commemoration of the Anzac Centenary-Report to Government', Australian Government, Department of Veterans' Affairs, accessed 8 June 2020, anzacportal.dva.gov.au/resources/national-commission-commemoration-anzac-centenary-reportgovernment. 
months earlier, Brendan Nelson, former leader of the Liberal Party and then director of the Australian War Memorial (AWM), underlined this aim when he stated that WWI 'is our story'; that 'no events so deeply wounded, divided, changed and ultimately defined us'; that 'we emerged [from it] with a greater belief in ourselves and a deeper understanding of what it means to be, an Australian'; and that a national character—an Anzac spirit—'binds us' together today. ${ }^{2}$

In the lead up to the centenary commemorations, the National Commission on the Commemoration of the Anzac Centenary and the federal Department of Veterans Affairs (DVA) commissioned research into the understandings of and attitudes towards Anzac, commemoration and the impending centenary by 'ordinary Australians'. Focus groups were conducted around Australia in regional and metropolitan areas; with people of various ages, ethnicities and household structures; and with people with varying levels of engagement with Anzac Day. ${ }^{3}$ Within these diverse groups, the resulting report claimed, there was near 'unanimous' support for commemorating Australia's military history 'in some form', even among those who were 'staunchly opposed to violence and war'. The report argued that this is because our military history, and particularly WWI and the Anzac Day tradition, have helped to '[craft] and [define] what it means to be an Australian'. ${ }^{4}$

This report, and the centenary commemorations as a whole, illustrate how the Australian Government has increasingly claimed ownership of the Anzac story and mobilised it to fashion a national identity. Both suggest that the government sees itself as the primary keeper, shaper and disseminator of WWI history and memory. In the public sphere, politicians, government officials and sympathetic public commentators have created and promoted an official national narrative that privileges Anzac at the expense of other nation-defining movements and moments. This overt politicisation of national history-in which the past is manipulated for party and ideological interests-extends beyond what might be considered history's inherently political nature.

2 Brendan Nelson, 'Address to the National Press Club: We're All Australians Now: 1918 and the War that Changed Us', Australian War Memorial, accessed 15 June 2019, www.awm.gov.au/ commemoration/speeches/AllAustraliansNow.

3 See Colmar Brunton, 'Department of Veterans' Affairs, "A Century of Service" Community Research', 11-12, accessed 8 June 2020, anzacportal.dva.gov.au/sites/default/files/docs/anzac-centuryservice-part1.pdf.

4 Brunton, 'Department of Veterans' Affairs', 1, 13-14. 
This politicisation has resulted in a growing conflation of Australia's national identity with an 'Anzac spirit', as illustrated by Nelson's speech and the research report discussed above. For many historians—such as Marilyn Lake and Henry Reynolds, who noted this conflation in their impactful What's Wrong with Anzac?: The Militarisation of Australian Historythis is deeply concerning. ${ }^{5}$ Yet, it is not a new phenomenon. Australian historians have been questioning the increasingly overt politicisation of history since it became embroiled in the cultural wars ignited by then Prime Minister John Howard in the early 2000s. As historians' authority was challenged by politicians and public commentators, important questions such as 'who owns the past?', 'what narratives should history tell?' and 'what forms should history take?' were hotly debated. ${ }^{6}$ Given the increasing politicisation and mobilisation of the Anzac story, how can historians engage 'ordinary Australians', communicate their disciplinary expertise and counter the militarisation of Australian history and identity?

\section{'Ordinary Australians'}

Several historians have explored the concept of 'ordinary Australians', how they engage with history, and the impact of history's politicisation on their ideas and impressions about their past. ${ }^{7}$ But who are 'ordinary Australians'? Since the end of World War II (WWII), the idea of the 'ordinary person' has gained currency in popular discourse and political journalism, leading to a turn towards the 'ordinary' in history and other social sciences. ${ }^{8}$ In the public sphere, politicians and the popular press use the idea of 'ordinary Australians' to both refer and appeal to an imagined

5 Marilyn Lake and Henry Reynolds, eds, What's Wrong with Anzac: The Militarisation of Australian History (Sydney: NewSouth Publishing, 2010).

6 Inga Clendinnen, 'The History Question: Who Owns the Past?', Quarterly Essay, no. 23 (2006).

$7 \quad$ For example, Anna Clark, 'Ordinary People’s History', History Australia 9, no. 1 (2012); Anna Clark, Private Lives Public History (Melbourne: Melbourne University Press, 2016); Paula Hamilton and Paul Ashton, 'At Home with the Past: Initial Findings from the Survey', Australian Cultural History Special Issue: Australians and the Past: A National Survey, ed. Paula Hamilton and Paul Ashton, no. 22 (2003); Paul Ashton and Paula Hamilton, History at the Crossroads: Australians and the Past (Sydney \& Canberra: Halstead Press, 2010).

8 Claire Langhamer, "Who the Hell Are Ordinary People?" Ordinariness as a Category of Historical Analysis', Transactions of the Royal Historical Society 28 (2018): 175-95, doi.org/10.1017/ S0080440118000099; Judith Brett and Anthony Moran, Ordinary People's Politics: Australians Talk about Life, Politics and the Future of Their Country (Melbourne: Pluto Press Australia, 2006), 1. 
general public. ${ }^{9}$ This is the imagined constituency that political leaders such as Howard and Nelson, and government organisations such as the AWM and DVA, try to influence when they politicise and militarise Australian history and identity.

But 'ordinariness' is not only an identity imposed upon Australians, it is also one many claim for themselves. This is what Anna Clark, and Judith Brett and Anthony Moran, argue in their studies of how 'ordinary Australians' engage with history and politics. Many Australians have 'a deep commitment to ordinariness'; it is how they often 'see, and describe, themselves'. Thus, this understanding of 'ordinary Australians' encompasses 'multiple dimensions of social difference' and includes Australians 'from all walks of life'. ${ }^{10}$ However, while this understanding is useful in that it allows us to examine a broad range of people whose diverse views have often been neglected in public debates over history, it is also problematic in that it raises questions about who actually considers themselves part of this elusive group. Do Indigenous Australians or those from culturally and linguistically diverse backgrounds see themselves as 'ordinary' or typical? What about those who have studied history but do not practise it? Or those with other experiences that may make them feel 'extraordinary'? As Claire Langhamer argued in her recent study of ordinariness as a category of historical analysis, what is deemed 'ordinary' is open to multiple contextually dependant interpretations. ${ }^{11}$ Its very vagueness means that it can 'encompass nearly everyone or ... describe no one at all'. ${ }^{12}$

Despite its obvious ambiguities, this article persists with the idea of 'ordinary Australians' and, in the process, unpacks it. I acknowledge the political use of the term to refer to an imagined general public whose historical consciousness is fought over in the public sphere because it is believed to be politically valuable. Yet, I argue that 'ordinary Australians' are much more than an imagined general public. They are a real group, though one that evades precise definition. For the most part, the 'ordinary

9 See, for example, commentary on John Howard and his 'battlers' and Scott Morrison and his 'quiet Australians' in Judith Brett, 'Relaxed and Comfortable: The Liberal Party's Australia', Quarterly Essay, no. 19 (2005): 30; Mark McKenna, 'Scott Morrison’s Quiet Australians', Monthly, July 2019, accessed 10 October 2019, www.themonthly.com.au/issue/2019/july/1561989600/mark-mckenna/ scott-morrison-s-quiet-australians.

10 Clark, 'Ordinary People’s History', 202-03; Brett and Moran, Ordinary People’s Politics, 2, 8.

11 Langhamer, "'Who the Hell Are Ordinary People?”, 177-78, 182-83.

12 Langhamer, "“Who the Hell Are Ordinary People?”, 85. 
Australians' I examine are people from all walks of life who do not have specialised knowledge, and who are not formal, active participants in history or public policy; they are not the historians, politicians and public commentators who try to shape responses to history, but they nevertheless have strong historical sensibilities. They include newspaper readers, school students, museum visitors, television watchers and travellers. At the same time, I do not wholly exclude historians or policymakers from the 'ordinary'; they too read newspapers and visit museums. Further, they are capable of self-appointing this identity, forming personal responses that reflect their authority as 'ordinary people' rather than as part of an 'elite'.

In this article, I bring together work on the ways that 'ordinary' people engage with history and scholarship on Anzac, identity and commemoration. I argue that 'ordinary' people engage with history in myriad ways, and that the ideas and impressions they form in response to these engagements are diverse and subjective, rather than conforming to an overarching official narrative. This article explores people's public and private engagements with history, using debates about the nature and significance of Anzac as a case study. First, it examines how people engage with history in the public sphere, specifically through schools, museums, public commemorations and the mainstream media. Second, it explores people's private engagements with history, which for many are far more influential in forming their ideas and impressions of their past. In particular, it explores the roles played by personal and family stories and by 'experiential' or 'immersive' history-fiction, film, television and visits to sites of historical significance. In this way, it illustrates that individuals' diverse ideas and impressions about their histories are shaped by the intertwining of public and private engagements, and national and personal stories. Thus, this article suggests that, while governments may try to dominate the official public narrative, the intertwined way in which 'ordinary Australians' develop their understandings of history and identity means that their ideas and impressions do not necessarily conform to this official narrative; hence, there are opportunities for historians to engage with 'ordinary Australians', and to encourage more complex and nuanced understandings that help to counter narrow and militaristic interpretations of Australian history. 


\section{Public Engagement}

Public engagements with history are one of the main ways in which 'ordinary Australians' develop a historical sensibility and form ideas and impressions about national history. However, over the past 20 years, this national history has been increasingly politicised through a series of public debates that have become known as the 'history wars'. These debates have been battlegrounds upon which politicians, academics, public commentators and 'ordinary Australians' have contested or advanced national narratives. ${ }^{13}$ In the early 2000s, the most hotly debated topics - race relations, the Stolen Generations, the White Australia policy and the influence of the British legacy-were encompassed in what then Prime Minister John Howard called the 'black armband' view of history. ${ }^{14}$ Howard claimed that the 'liberal-left intelligentsia' was promoting an 'unpatriotic and negative' view of Australian history and that Australians deserved to feel 'comfortable and relaxed' about their past. ${ }^{15}$ To counter this, he strove to enforce 'a positive, nationalistic' interpretation of our history, focusing particularly on Anzac - that is, the story of the Australian Army's role in the WWI Gallipoli campaign — which quickly regained its earlier dominance as the 'creation myth' of 'White Australia'. ${ }^{16}$

The meaning and relevance of the Anzac story has been interpreted and reinterpreted over the last 100 years, waxing and waning in the public imagination. As Carolyn Holbrook has argued, drawing on E. P. Thompson, memory of Anzac is ... "a relationship and not a thing"'. ${ }^{17}$ Each generation has made Anzac its own, influenced by the political, historical and ideological shifts that have bent and moulded the narrative to meet society's current needs. ${ }^{18}$ In the period immediately after WWI, the narrative that was constructed framed Gallipoli and the war in general

13 Andrew Bonnell and Martin Crotty, 'Australia’s History under Howard, 1996-2007', The ANNALS of the American Academy of Political and Social Science 617, no. 1 (2008): 150, doi.org/10.1177/ 0002716207310818; Clark, Private Lives Public History, 98-99.

14 Bonnell and Crotty, 'Australia's History under Howard', 152.

15 Bonnell and Crotty, 'Australia's History under Howard', 153; Brett, 'Relaxed and Comfortable', 30.

16 Bonnell and Crotty, 'Australia’s History under Howard', 153; Marilyn Lake, 'Introduction: What Have You Done For Your Country', in What's Wrong with Anzac: The Militarisation of Australian History, ed. Marilyn Lake and Henry Reynolds (Sydney: NewSouth Publishing, 2010), 1.

17 Carolyn Holbrook, Anzac: The Unauthorised Biography (Sydney: NewSouth Publishing, 2014), 207.

18 Clendinnen, 'The History Question', 10-14; Mark McKenna, 'Anzac Day: How Did It Become Australia's National Day?', in What's Wrong with Anzac: The Militarisation of Australian History, ed. Marilyn Lake and Henry Reynolds (Sydney: NewSouth Publishing, 2010), 111, 120-21; Holbrook, Anzac, 3, 6, 118-19, 207. 
as a 'nation-making' event fought by 'legendary' and 'furious' 'bushmansoldiers' for the maintenance of the British race and empire. ${ }^{19}$ After WWII, this version declined and by the Vietnam era had almost completely fallen out of favour, condemned as militaristic and politically conservative. For this generation, WWI was 'a tragic debacle that was glorified each Anzac Day by a group of racist chauvinist old boozers' ${ }^{20}$ However, the $1980 \mathrm{~s}$ and 1990s saw the beginning of an Anzac revival that reframed the myth around the 'tragedy and sacrifice' of individual soldiers and 'stories of mateship, courage and trauma'. ${ }^{21}$ By the time Howard re-centred Anzac and Gallipoli as Australia's 'nation-making' creation myth, it had already regained a significant place in Australian understandings of nationalism and identity. ${ }^{22}$ Many people, such as historian Bill Gammage and Labor prime ministers Bob Hawke and Paul Keating, and events, such as the 1988 bicentenary of white settlement and the 2001 centenary of Federation, contributed to and shaped this revival. ${ }^{23}$ In addition, Hawke and Keating politicised Australia's military history and mobilised it to develop particular national identities. However, it was under Howard that Anzac became entrenched as 'the key pillar of national pride' and that federal departments like DVA and Defence became protectors of memorials, 'promoters' of ceremony and, most significantly, 'patron[s] of history'. ${ }^{24}$

This new interpretation of the Anzac myth, supported and funded by government, entered public consciousness through schools, public commemorations and museums, and the mainstream media. It claimed that the Anzac spirit was the backbone of Australian national identity; that WWI and the Gallipoli campaign represented 'the supreme test of nationhood' and the birth of our nation; and that our 'innocent, brave young men' sacrificed themselves for the freedoms that we enjoy today. ${ }^{25}$ Schools have performed a central role in inculcating this nationalistic and militaristic interpretation of Australian history. From the early 2000s, DVA has bombarded them with learning resources, essay prizes and other funding to encourage ever more commemoration and education about Australia's

19 Holbrook, Anzac, 6, 139; McKenna, 'Anzac Day', 120-21.

20 Holbrook, Anzac, 6, 46, 116-22.

21 Holbrook, Anzac, 135-43.

22 Holbrook, Anzac, 6.

23 Bonnell and Crotty, 'Australia's History under Howard', 151-52; McKenna, 'Anzac Day', 113-16; Holbrook, Anzac, 166-206.

24 McKenna, 'Anzac Day', 124; Ken Inglis, Sacred Places: War Memorials in the Australian Landscape, 3rd ed. (Melbourne: Melbourne University Press, 2008), 555.

25 Brunton, 'Department of Veterans' Affairs', 14-15; McKenna, 'Anzac Day', 2, 24, 110, 153, 158. 
military history. ${ }^{26}$ This has led to a partial reinvigoration of Australian history in the classroom. In her research, Anna Clark found that, while Australian history as a whole still languishes in schools, Anzac stands out as a topic that most students are enthused about. ${ }^{27}$ For many, their personal interest in Anzac is fuelled by the 'sense of national identity it evokes' ${ }^{28}$ Clark's interviews indicate that many students equate 'being Australian' with an 'Anzac spirit' or 'national character' that was forged on the battlefields of WWI. ${ }^{29}$ They often uncritically regurgitate the myth that Anzac represents 'our birth as a nation' and 'what it means to be Australian'. ${ }^{30}$

Public institutions like museums and memorials are also instrumental in transmitting this myth in the public sphere, particularly the AWM. This national memorial forms the 'core of the nation's tribute' to Australian service personnel through its dual commemorative and pedagogical roles. Its primary purposes are to 'commemorate the sacrifices of those Australians who have died at war' and to help Australians 'remember, interpret and understand' the experience and impact of war in Australian society. Therefore, it plays a significant role in informing individual Australian's ideas and impressions of this part of their national history. ${ }^{31}$ However, the way it fulfils these purposes is shaped by its political, social and cultural context, especially considering it is a national institution, bound by legislation and dependent on government funding.

In recent years, there has been a decided shift towards a more 'conservative ethos' and a 'cautious traditionalism' in the way the AWM constructs history. ${ }^{32}$ Its interpretation and presentation of Australia's experiences of

26 Marilyn Lake, 'How Do School Children Learn about the Spirit of Anzac?', in What's Wrong with Anzac: The Militarisation of Australian History, ed. Marilyn Lake and Henry Reynolds (Sydney: NewSouth Publishing, 2010), 144-49; Inglis, Sacred Places, 556-58.

27 Clark, Private Lives Public History, 72-73; Anna Clark, History's Children: History Wars in the Classroom (Sydney: NewSouth Publishing, 2007), 44.

28 Clark, History's Children, 46. Similar sentiments are expressed in Bruce Scates, 'Walking with History: Children, Pilgrimage and War's "Restless Memory", Australian Cultural History Special Issue: Australians and the Past: A National Survey, ed. Paula Hamilton and Paul Ashton, no. 22 (2003).

29 Clark, History's Children, 45-47.

30 See Morgan from Canberra, Robert from Perth, and Edie, Anthony and Beth from Central Australia, quoted in Clark, History's Children, 43, 45, 47. A similar point is made by Henry Reynolds, 'Are Nations Really Made in War?', What's Wrong with Anzac: The Militarisation of Australian History, ed. Marilyn Lake and Henry Reynolds (Sydney: NewSouth Publishing, 2010), 24.

31 'About the Australian War Memorial', Australian War Memorial, accessed 28 June 2018, www. awm.gov.au/about; 'History of the Australian War Memorial', Australian War Memorial, accessed 28 June 2018, www.awm.gov.au/about/organisation/history.

32 Peter Stanley, 'War without End', in Australian History Now, ed. Anna Clark and Paul Ashton (Sydney: NewSouth Publishing, 2013), 93-94. A similar point is made by Inglis, Sacred Places, 496. 
war is distinctly nationalistic and militaristic, privileging battle-driven accounts and national myths over more collective, universal stories of war that have become common in other war museums around the world. This interpretation is evident in the recently refurbished First World War galleries, where many of the displays emphasise Australian military might and glorify the values that have come to be associated with Anzac. It is also evident in the nightly Last Post Ceremony, which enforces a national narrative that reflects the current Anzac mythology. This ceremony follows a strict formula, drawn from the script of traditional remembrance services: national anthem, piper's lament, the laying of wreaths and the reciting of the Ode. ${ }^{33}$ Each ceremony tells the story of an individual solider and concludes with the words:

This is but one of the many stories of service and sacrifice told here at the Australian War Memorial. We now remember [individual's name], who gave his life for us, for our freedoms and in the hope for a better world. ${ }^{34}$

The First World War galleries and Last Post Ceremony illustrate how the AWM transmits and reinforces the current version of the Anzac myth. The AWM tends to avoid controversial topics and presents commemoration as a 'sombre celebration', leaving visitors with an 'uncritical account of Australia's involvement in war'. ${ }^{35}$ This militaristic and nationalistic interpretation of Australian history concerns historians such as Clark, Lake, McKenna and Reynolds who consider that, rather than generating genuine historical understanding, it encourages 'nationalist sentiment' and incomplete understandings of the past. ${ }^{36}$ This, in turn, discourages critical engagement with history and promotes the view that Anzac is 'sacred' and thus above questioning. ${ }^{37}$

33 'Last Post Ceremony', Australian War Memorial, accessed 5 July 2018, www.awm.gov.au/ commemoration/last-post-ceremony.

34 'AWM Last Post', YouTube, accessed 8 June 2020, www.youtube.com/channel/UCKmio2JTTL pxC3gniK1f2IA.

35 Guy Hansen, 'Museums and the Great War: A Curator's Perspective on the History of Anzac', in Nation, Memory and Great War Commemoration: Mobilising the Past in Europe, Australia and New Zealand, ed. Shanti Sumartojo and Ben Wellings (Oxford: Peter Lang, 2014), 245-46. A similar point is made by Inglis, Sacred Places, 501.

36 Reynolds, 'Are Nations Really Made in War?', 25-27; Lake, 'How Do School Children Learn',

137, 153; Clark, History's Children, 45-46, 51.

37 Reynolds, 'Are Nations Really Made in War?', 24-35; Mark McKenna quoted in Clendinnen, 'The History Question', 9. 
Nevertheless, Anzac is questioned, discussed and debated openly in the public sphere by historians, public commentators and 'ordinary Australians', revealing the diversity of responses to this national story and the deep divisions that they imply. Critical engagement with Anzac grew in the lead-up to, and throughout, the WWI centenary commemorations, becoming the latest iteration of the history wars. Although many 'ordinary Australians' (those who are not actively involved in shaping national narratives) may not be familiar with the term 'history wars' or the details of Australia's military history, most would be aware that our national history is contested and many would have their own ideas and impressions about Anzac. ${ }^{38}$ Often these do not conform to the official national myth discussed above.

The mainstream media, and particularly discussion forums on items published by these media, have allowed 'ordinary' people to contribute to wider public debates about the meaning and relevance of Anzac. For example, an essay written by prominent historian Marilyn Lake and published by the Age in 2009 inspired a diverse range of responses. Many passionate and patriotic responders were outraged that Anzac's authority and relevance were being critiqued and questioned. They expressed indignation with Lake's use of the term 'Anzac myth' and decried her as 'un-Australian and disrespectful'. ${ }^{39}$ However, other responders were more reflective, seeming to welcome the opportunity to question what has become a dominant myth, and offering their own critiques of Anzac and the ways it has been incorporated into national history and identity. ${ }^{40}$ For example, one person wrote that:

Australia needs to drop the sentimental garbage that ANZAC day has become. The soldiers of Gallipoli must be honoured however they are not apostles to be given religious reverence. ${ }^{41}$

38 Clark, Private Lives Public History, 100-01; Brunton, 'Department of Veterans' Affairs', 1, 37.

39 Lake, 'Introduction', 4. See, for example, comments by Sinistra (24 April 2009, 10:32 am), Anne Rinkin (24 April 2009, 12:14 am), David (24 April 2009, 12:40 am), Nevillew (23 April 2009, 7:32 pm), Mother of Four (23 April 2009, 3:40 pm), in Marilyn Lake, 'Creation of a Nation?', 2009, accessed 1 May 2019, blogs.theage.com.au/yoursay/archives/2009/04/creation_of_a_n.html?page= fullpage\#comments (site discontinued).

40 See, for example, comments by LeonT (24 April 2009, 11:58 am), mel (23 April 2009, 4:49 pm), I drink lattees and I vote (23 April 2009, 4:27 pm), in Lake, 'Creation of a Nation?'.

41 Quoted in Lake, 'Introduction', 4. 
Another argued that honouring and reflecting on 'the grief and horror' that characterised many people's experiences of WWI has 'absolutely nothing to do with honouring sacrifices ... to safeguard [our] freedom ... That is a myth created by outsiders'. ${ }^{42}$ Some responders demanded the acknowledgement of different interpretations, such as the internationalism of the Gallipoli campaign; that the Gallipoli landing was an invasion rather than a defence of our nation, freedom or way of life; and that Anzac represents not a moment of national autonomy on the world stage, but an expression of our subservience to Imperial Britain. ${ }^{43}$

Similarly, and notwithstanding their key role in promoting the Anzac myth, schools also act as sites of critique, allowing both teachers and students to question or reject the official story in favour of more critical engagement. Although many of the school students Clark interviewed expressed an 'emotive national pride in the past' some, such as Ophelia from Adelaide and Jiang from Brisbane, welcomed the opportunity to explore the topic from a variety of perspectives, indicating that their interest was motivated by 'discussion and critique rather than sentiment'. ${ }^{44}$ For some, the international perspective was particularly appealing. Two students in Clark's study, Ramah and Yasmin from a Sydney Islamic school, thought that this international element made Australians at war 'one of the best subjects'. ${ }^{45}$ The increased importance of this international perspective could reflect Australia's large multicultural population. Being able to place Australian history within a broader global context could allow students to form more complex impressions of Australian history and how it contributes to their own identity. However, some students also explicitly rejected the link between Australia's military history and national identity, struggling to see how it speaks to their contemporary experiences in which war has played a minor role. ${ }^{46}$ Wary of the risk of jingoism, many teachers aim to introduce these critical reflections and balanced interpretations in the classroom to help students form their own ideas and impressions about their histories. ${ }^{47}$

42 Leigh (24 April 2009, 4:45 pm) in Lake, 'Creation of a Nation?'.

43 See comments in Lake, 'Introduction', 4, 9, 10. See also comments by Strange (24 April 2009, 11:13 am), I drink lattees and I vote (23 April 2009, 4:27 pm), Mikey (23 April 2009, 11:12 pm), in Lake, 'Creation of a Nation?'.

44 Clark, History's Children, 57-59.

45 Clark, History's Children, 59-60.

46 See comments from Hugh and Maddison from Perth in Clark, History's Children, 60.

47 Clark, History's Children, 58-59. 
As critical engagement grows, some public institutions such as the National Anzac Centre (NAC) in Albany, Western Australia, are also trying to shape people's ideas and impressions to accommodate new, more nuanced interpretations of Anzac. Established in 2014 as part of centenary initiatives, the NAC has consciously developed contemporary approaches to commemoration and pedagogy. From its inception, its curators wanted to avoid a celebratory or nationalistic interpretation of history. They felt sceptical about trying to 'evoke' the 'Anzac spirit' or 'Anzac legend'. Instead, they wanted to focus on 'reality and remembrance', and telling the story of war 'as it was, no more, no less' through the primacy of individuals' personal stories and testimonies. ${ }^{48}$ These individuals are the heart of the NAC's curatorial vision; they act as visitors' guides, allowing the museum to tell a diverse story of war. The NAC's narrative acknowledges the different and shared experiences of Anzac combatants and non-combatants (Australian and New Zealand, including Indigenous servicemen) as well as some of their Allies and former enemies, both during and after the war. Extending beyond the battlefield, the NAC also presents diversity through its exploration of civilian experiences and emphasis on the enduring impact of war on Australian society, particularly in the postwar period.

In contrast to the AWM, the NAC departs significantly from traditional ways of commemorating and teaching about WWI. It works within a context of contemporary museum practice that privileges the authority of personal testimony and the value of immersive experiences, and thus provides ways for people to engage critically with history. ${ }^{49}$ In addition, while initially funded by government, the NAC is now an independent body, which undoubtedly influences the style of history it can present. Therefore, while public engagements with history tend to be the primary transmitters of the official, government-endorsed Anzac myth, they also allow people to develop complex, critical and diverse ideas and impressions about their history that are not confined to the official version.

48 Stephen Anstey, National Anzac Centre, Albany, interview by Lucinda Fretwell, April 2019.

49 For changes in contemporary museum practice and the rise of the witness see Jay Winter, Remembering War: The Great War Between Memory and History in the Twentieth Century (New Haven \& London: Yale University Press, 2006), 6-8, 27-28, 238-71; Steffi de Jong, The Witness as Object: Video Testimony in Memorial Museums (New York \& Oxford: Berghahn, 2018); Karen Shelby, Belgian Museums and the Great War: Politics, Memory, and Commerce (New York: Routledge, 2018). 


\section{Personal Engagement}

Individual responses to public engagements with history are inextricably linked to personal contexts. Factors such as age, education, values, experiences, political positions, and family, cultural and ethnic backgrounds, undoubtedly influence people's opinions and attitudes towards history in profound and subjective ways. This can be seen in the online discussion about Lake's essay in which people often explicitly linked their ideas about the Anzac story to their own contexts. For example, 'graham' identified himself as a member of the anti-Vietnam War generation with his reference to Eric Bogle's song 'And the Band Played Waltzing Matilda'. This context, combined with his memories of his uncle 'coughing blood ... and being a perpetual drunk and absolutely refusing to talk about his experiences on the Western Front', influenced his view that WWI was a 'folly' and that Anzac commemorations have been 'blown out of all proportion', becoming more exclusionary and celebratory in recent years. ${ }^{50}$

Similarly, people's contexts and personal connections to national history influence how they engage with public commemorations such as Anzac Day. Older Australians, such as the historian Inga Clendinnen, have memories of Anzac Day in the interwar period, when war was still fresh, mourning was still an integral part of the practice and it was still very much a sacred day. For Clendinnen, Anzac Day was 'a personal possession' that held her 'childhood memories of family and neighbourhood'. ${ }^{51}$ This, along with the fact that her father served in WWI, undoubtedly shaped her attitude towards its legacies and her disdain for modern commemorations that have 'displaced the mournful dignity of "[her]" Anzac Day'.52 Indigenous Australians also have specific experiences of Anzac Day. For some communities, it stands in contrast to Australia Day as a 'collective moment' that connects them to the national story. ${ }^{53}$ But, for others, the historic lack of recognition of the military contribution of Indigenous servicemen and women makes Anzac Day feel like 'a party that we have not been invited to' ${ }^{54}$ It is also the case that a substantial number of 'ordinary Australians' come from culturally and linguistically diverse backgrounds. While respectful of their adopted

50 graham (24 April 2009, 4:28 am) in Lake, 'Creation of a Nation?'.

51 Clendinnen, 'The History Question', 12-13.

52 Clendinnen, 'The History Question', 13.

53 Clark, Private Lives Public History, 91.

54 Brunton, 'Department of Veterans' Affairs', 3, 15. 
country's traditions, these Australians generally do not share the same personal connection to this part of Australia's national history and so are often disengaged from it. ${ }^{55} \mathrm{~A}$ Vietnamese migrant, Thanh, explained that Anzac is generally understood by multicultural groups 'but not felt. ${ }^{56}$ The nature of these personal connections, or lack thereof, influence the ways people think and feel about their history.

By the same token, the changing nature of both the official Anzac myth and public commemoration of it can influence people's ability to form personal connections with this national story-in some instances engaging broader demographics and in other cases alienating them. Graeme Davison has argued that Anzac became more 'universal' in the late twentieth century, focusing on 'a generalised sense of goodwill' that has allowed it to become 'what you want to make of it'. ${ }^{57}$ This has opened it up, allowing more people to relate the national story to their own experiences and identity. In contrast to Thanh, Sarah Noori, an Afghani refugee who experienced war from a young age before arriving in Australia, described how her experiences illustrate that 'the spirit of Anzac-determination, generosity and kindness—is still relevant [to] Australians today'.$^{58}$ Similarly, Dan Vo, a first generation Australian whose parents were Vietnamese refugees, described how 'everyone has something of the Anzac spirit inside them'. ${ }^{59}$ This indicates that new, more universal, interpretations of the Anzac myth have allowed it to speak to broader experiences, helping some Australians-even those with no obvious personal link to Anzac — to create a sense of Australian identity and make deeper personal connections to national stories.

At the same time, these new interpretations of Anzac have alienated parts of the population, most notably current service personnel. The elevation of Anzac to the sacred, and the intensity of the myth, 'paints glory and honour so thickly on those in the military that it almost suffocates them', argues ex-serviceman James Brown. ${ }^{60}$ In current commemoration, the 'Anzac' soldier is often deified, transformed into

55 Brunton, 'Department of Veterans' Affairs', 1-3.

56 Clark, Private Lives Public History, 91.

57 Graeme Davison, 'The Habit of Commemoration and the Revival of Anzac Day', Australian Cultural History Special Issue: Australians and the Past: A National Survey, ed. Paula Hamilton and Paul Ashton, no. 22 (2003): 80.

58 Noori quoted in Clark, History's Children, 44.

59 Vo quoted in Davison, 'The Habit of Commemoration', 80.

60 James Brown, Anzac's Long Shadow: The Cost of Our National Obsession (Collingwood: Black Inc., 2014), 3. 
a 'heroic giant', a 'tough, fearless egalitarian digger' who embodies the very values of what it means to be Australian. ${ }^{61}$ As a result, current service personnel may come back from active service feeling 'ashamed' that they have not 'measured up' to the legend. ${ }^{62}$ When this occurs, the current Anzac myth denies them 'a rounded human complexion', a normalcy that accommodates both 'courage and cowardice, compassion and cruelty, stoicism and vulnerability'. ${ }^{63}$ The deification of Anzac also means that contemporary commemoration tends to focus on the heroics of Gallipoli and WWI at the expense of other conflicts and peacekeeping missions. A commenter on Lake's discussion forum explained how, as an 'ex member of the Australian Defence Force', they felt 'disturbed' when an Anzac Day ceremony they attended focused exclusively on Gallipoli and made no mention of the servicepeople currently 'in Iraq, Afghanistan and East Timor' nor the 'countless Vietnam and Korean War vets present'. ${ }^{64}$ For some current and ex-service personnel, the focus on Gallipoli, the sacredness of the Anzac legend and the almost celebratory nature of contemporary commemoration alienates them from it, acting as a barrier to forming positive personal connections with their history and national stories, which influences the ideas and impressions they form.

The official Anzac story is undoubtedly politicised and mobilised in the public sphere to enforce a particular Australian identity. However, while it may be prevalent, it is not universally accepted. Individual Australian's ideas and impressions of this history and the ways it influences their personal identity are diverse and subjective, influenced by a mixture of their unique engagements and personal contexts. This suggests that there are opportunities for historians to engage with 'ordinary Australians' in the public sphere and to generate more complex understandings of history that challenge narrow, militaristic interpretations.

While public engagements are important, private engagements with history are also a significant way in which 'ordinary Australians' develop a historical sensibility and form ideas and impressions about their pasts. In fact, research by Clark, and Hamilton and Ashton, indicates that most Australians' primary connections with their history occur in the private sphere-through activities such as family discussions, looking at old photos or heirlooms, studying family trees, watching films and television,

61 Brown, Anzac's Long Shadow, 4.

62 Brown, Anzac's Long Shadow, 4.

63 Captain Ashley Judd and Paul Daley quoted in Brown, Anzac's Long Shadow, 109-10.

64 Troy Dafter (23 April 2009, 12:40 pm) in Lake, 'Creation of a Nation?'. 
reading books or visiting places. ${ }^{65}$ These private engagements are arguably more important in shaping people's thoughts, ideas and impressions about their pasts and identities than official national histories; this is because the emotional and imaginative appeal of such engagements enables people to connect with them and relate them to their everyday lives and sense of self more easily. Although seemingly removed from the influence of official narrations of the Anzac myth, the following examples illustrate how some Australians adopt and internalise these interpretations, allowing them to influence their private engagements with history. However, this also means that historians - and particularly public historians working with what Hamilton and Ashton call 'the past for public consumption' ${ }^{66}$ - can influence private engagements in similar ways.

Personal and family stories are among the principal ways that individual Australians connect with their history in the private sphere. The Anzac revival - the reinterpretation of the myth and the increasing political interest in Anzac in the 1980s and 1990s-coincided with 'a profound shift in the way that memory' of WWI was transmitted. The passing of the original Anzacs and the declining influence of the Returned and Services League left a void in which family historians emerged as 'significant custodians of Great War memory'. ${ }^{67}$ At the same time, two other major shifts fundamentally changed how we remember and commemorate war. First, the 'witness' emerged as a valuable bringer of a 'truth more "truthful"' than the official histories - that of direct personal experience and individual memory. ${ }^{68}$ Second, a proliferation of new social and cultural histories gave rise to a more democratised history that placed victims, whether soldiers or civilians, at the centre of the narrative. ${ }^{69}$ These changes in public understandings of commemoration and remembrance allowed 'ordinary' people to see their personal and family histories as part of a larger national story and as legitimately informing national history. ${ }^{70}$

Similarly, changing public ways of thinking about war influenced by memory studies and psychology have led to new ways of interrogating family stories. Family historians are now far more likely to read against the grain when studying their relations' diaries or letters, asking new questions

65 Hamilton and Ashton, 'At Home with the Past'; Clark, Private Lives Public History.

66 Hamilton and Ashton, 'At Home with the Past', 6.

67 Holbrook, Anzac, 144.

68 Winter, Remembering War, 7, 27, 50, 238; Shelby, Belgian Museums and the Great War, 85-86.

69 Winter, Remembering War, 6.

70 Holbrook, Anzac, 151-52, 164. 
about 'trauma, shell shock and psychological well-being'. ${ }^{71}$ In turn, these new interpretations have helped to rehabilitate the public image of the Anzac story, transforming the diggers into 'traumatised victims worthy of our sympathy, rather than bloodthirsty warriors or (in their later years) elderly men with antiquated ideas'.$^{72}$ One family historian, Julie Cattlin, who was once part of the anti-war movement inspired by the conflict in Vietnam, has developed more complex views about war since working on her family history. She now marches on Anzac Day, believing it is 'not so much about allies and enemies' or 'overt displays of nationalism', but rather about 'human beings who have been destroyed by war'. ${ }^{73}$ Here we can see a reciprocal relationship in which changes in public understandings of Anzac influence private ways of engaging, in turn influencing the public again.

Family histories such as these contribute to both individual and collective understandings of the past. Ashton and Hamilton argue that family history is about 'developing self awareness ... and locating one's identity in space and time' rather than 'understanding' broader history. ${ }^{74} \mathrm{But}$, as Jay Winter notes, war is one of the key ways individuals connect their family or local stories with 'bigger, more universal narratives', and thus family histories that centre on war are about the personal and the national. ${ }^{75}$ Another family historian, Lynette Oates, felt that, through her personal history project exploring her uncle's wartime experiences, she not only went on a 'journey of self-discovery', developing 'a greater understanding of who I am, and sometimes, why I am as I am', but also gained 'enormous pride in my nation and the values that have come down to me'. ${ }^{76}$ Therefore, engaging with family history shapes both individual and collective identities and sense of belonging. Its emotive and personal nature allows individuals to make deep personal connections to their history, which in turn shapes their ideas and impressions about it.

Many 'ordinary Australians' also create personal connections with their pasts through 'experiential' or 'immersive' history, such as fiction, films, television and visits to sites of historical significance. According to Hamilton and Ashton's 2003 study, fictional and televised history are key

71 Holbrook, Anzac, 165.

72 Holbrook, Anzac, 165.

73 Holbrook, Anzac, 163-64.

74 Ashton and Hamilton, History at the Crossroads, 27, 34.

75 Winter, Remembering War, 6, 40.

76 Holbrook, Anzac, 153, 160. 
ways that people engage with the past. ${ }^{77}$ This is even more the case today, with the increasing abundance of, and access to, these media in recent decades. In a 2010 study, Hamilton and Ashton identified the possible role of historical computer games in influencing and shaping 'historical understanding..$^{78}$ A decade later, with the development of ever more immersive technology, such as virtual reality, it is becoming increasingly possible to 'see' and 'experience' history, and it will be instructive to follow what effect this has in shaping people's ideas and impressions of the past.

Although many historians have expressed concern about the accuracy of these kinds of experiential or immersive history, their appeal is undeniable. ${ }^{79}$ Fictionalised history can be 'history given life and flesh'; stories and narratives can 'enliven' the past and impart more than just 'facts' ${ }^{80}$ Visual media, such as television and film, offer an immediate and tangible connection with the past and thus can have incredible 'visceral power'. ${ }^{81}$ In other words, fictional and televised history give 'ordinary' people a sense of what it might have felt like to 'be there'. By providing such personalised insights, these forms of history generate more personal connections with the past than formal or official history. For some people, this helps them better understand family stories. For example, one man whose father never talked about his war experiences reflected that, as a child, he 'couldn't give a shit about documentaries or why my dad was the way he was', but, as he aged, these became a key way to try to understand his father and his experiences. ${ }^{82}$ In this way, fictional or televised history can mediate between personal memory and experience and public or collective memory, generating 'everyday forms of historical understanding' that coexist with, rather than supplant, more formal or official history. ${ }^{83}$

Similarly, places and sites of historical significance offer 'ordinary' people an opportunity to 'experience the past', see where 'real history' took place and gain 'emotional understandings'. ${ }^{84}$ For example, people visit WWI battlefields to "'connect" with Australia's history', feel a 'nostalgia' and

77 Hamilton and Ashton, 'At Home with the Past', 11.

78 Ashton and Hamilton, History at the Crossroads, 120.

79 For example, see Clendinnen, 'The History Question'; Jay Winter, 'Museums and the Representation of War', in Does War Belong in Museums?, ed. Wolfgang Muchitsch (Transcript Verlag, 2013).

80 Clendinnen, 'The History Question', 17; Tony Birch, 'The Trouble With History' in Australian History Now, ed. Anna Clark and Paul Ashton (Sydney: NewSouth Publishing, 2013), 235-37.

81 Michelle Arrow, "I Want to Be a TV Historian When I Grow Ip!": On Being a Rewind Historian', Public History Review 12 (2006): 81, 83, doi.org/10.5130/phrj.v12i0.199.

82 Ashton and Hamilton, History at the Crossroads, 119.

83 Ashton and Hamilton, History at the Crossroads, 115.

84 Clark, Private Lives Public History, 122, 126-27. 
gain a sense and appreciation of 'the harsh reality' of that experience. ${ }^{85}$ These motivations are evident in Bruce Scates's study of high school students who visited the battlefields of Gallipoli and the Western Front in a kind of pilgrimage. For some students, it represented an opportunity to connect with both national history and identity, like Dave who saw the Gallipoli peninsula as 'the Australian Mecca, a place where we can reflect upon ourselves and what it means to be Australian'. ${ }^{86}$ For Erika, whose 'great-great-uncle was killed at Gallipoli when he was only eighteen', it offered an opportunity to gain deeper understandings of their personal and family history. Through her pilgrimage, Erika hoped to be able to understand 'what drove him to offer his life so willingly'. ${ }^{87}$ These personal and family connections, and the emotional engagement they created, were powerful influencers in shaping students' responses to their journey:

Elise found her uncle's name chiselled in the cold white stone at Lone Pine. She traced her fingers, softly, deliberately, along each of the letters. 'Strange', she scribbled in her diary, this is 'my own flesh and blood'. Rebecca thought part of herself lay in the heavy clay of France; Todd crumbled down by the grave of his greatuncle: 'It's my name', he spluttered, 'my name on the headstone'. ${ }^{88}$

However, where personal connections are not pre-existing, pilgrimages can offer the opportunity to develop them. Students on Scates's pilgrimage talked about how the stories of the soldiers they commemorated would 'stick with [them] for the rest of [their] lives'. It was these personal connections with individual stories that made their pilgrimage 'meaningful'. ${ }^{89}$ Students found the pilgrimage strengthened their personal connections to the nation, with many recording feelings of patriotism and national pride, especially in response to Anzac Day ceremonies at Gallipoli. ${ }^{90}$ In this way, journeys or pilgrimages to sites of historical significance are both 'collective narrative[s]' and 'deeply personal journeys. ${ }^{91}$ They speak to 'family identity', 'national identity' and 'a broader "human identity", and they offer an opportunity both to deepen personal connections with history and to forge new ones. ${ }^{92}$

85 Brunton, 'Department of Veterans' Affairs', 16.

86 Dave quoted in Scates, 'Walking with History', 83.

87 Erika quoted in Scates, 'Walking with History', 83-84.

88 Scates, 'Walking with History', 90.

89 Quoted in Scates, 'Walking with History', 91, 92.

90 Scates, 'Walking with History', 97-98, especially Erika's response, 87.

91 Scates, 'Walking with History', 84.

92 Holbrook, Anzac, 157. 
Engaging with personal or family stories and experiential or immersive history are therefore significant ways 'ordinary Australians' develop their historical sensibilities. What makes these types of engagements so influential is that they tap into emotions as well as intellect, and this emotional connection to the past-whether it is historically accurate or not-plays a significant role in shaping individuals' ideas and impressions about their histories. This then offers an opportunity for historians, and especially those working in public history, to be more involved in influencing everyday forms of historical understanding that people develop in the private sphere.

\section{Conclusion}

People's ideas and impressions of their history and how it informs their identity emerge through the intertwinement of both public and private engagements and national and personal stories, meaning that these ideas and impressions are diverse and subjective. Importantly, this also means that, while official narrations of the Anzac myth are influential, they are not omnipotent. Politicians and government organisations do not have a monopoly on the Anzac story. By engaging with 'ordinary Australians' in both the public and private sphere, historians can encourage more complex and nuanced understandings of Anzac that counter narrow and militaristic interpretations. Of course, Anzac is not the only part of Australian history that is politicised. Our Indigenous and colonial histories are tense and controversial because they remain politicised and unresolved. Further, Anzac does not represent the epitome of our national identity. Here too, historians can, and should, try to engage all Australians to counter the ideological production of mythologies and militarised national histories by politicians and public commentators. Because of the complex and intertwined way that individuals develop their sense of history and identity, politicians cannot wholly claim history for their own interests. Historians always have opportunities in both the public and private sphere to reclaim history, assert their disciplinary expertise, and influence 'ordinary' people's ideas and impressions about the past. 
This text is taken from ANU Historical Journal II: Number 2, published 2020 by ANU Press, The Australian National University, Canberra, Australia.

doi.org/10.22459/ANUHJII.2020.08 